Page 1 of 2 Proj.

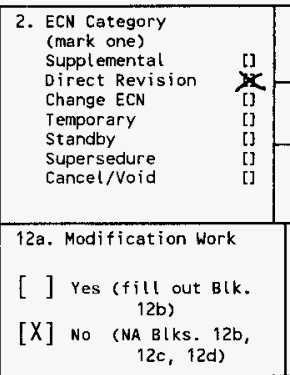

13a. Description of Change
3. Originator's Name, Organization, MSIN, and Telephone No.

R. D Crowe, SA\&NE, HO-32 [] Yes [X] No

6. Project Title/No./Work Order No. TWRS FSA/BIO

9. Document Numbers Changed by this ECN (includes sheet no. and rev.) WHC-SD-WM-CN-059, rev. 0

12b. Work Package $12 \mathrm{c}$. Modification Work Complete No.

$N / A$ N/A TWRS

$N / A$ $N / A$
5. Date $09 / 19 / 96$

7. Bldg./Sys./Fac. No. 8. Approval Designator

10. Related ECN No(s).

11. Related PO No

$N / A$

12d. Restored to Original Condi tion (Temp. or Standby ECN only)

Design Authority/Cog. Engineer Signature \& Date Signature \& Date

[X] No

The lower flammability limit for gasoline was changed from $1.4 \%$ to $1.3 \%$ resulting in a small change in numerous calculated values, however, no significant change occurred. Minor editorial comments were also incorporated.

14a. Just ification (mark one)

Criteria Change [X] Design Improvement [ ] Environnental

As-found []

facilitate Const

[]

Const. Error/Omission

[ ]

Facility Deactivation

14b. Justification Details

$N / A$

15. Distribution (include name, MSIN, and no. of copies)

See attached. 


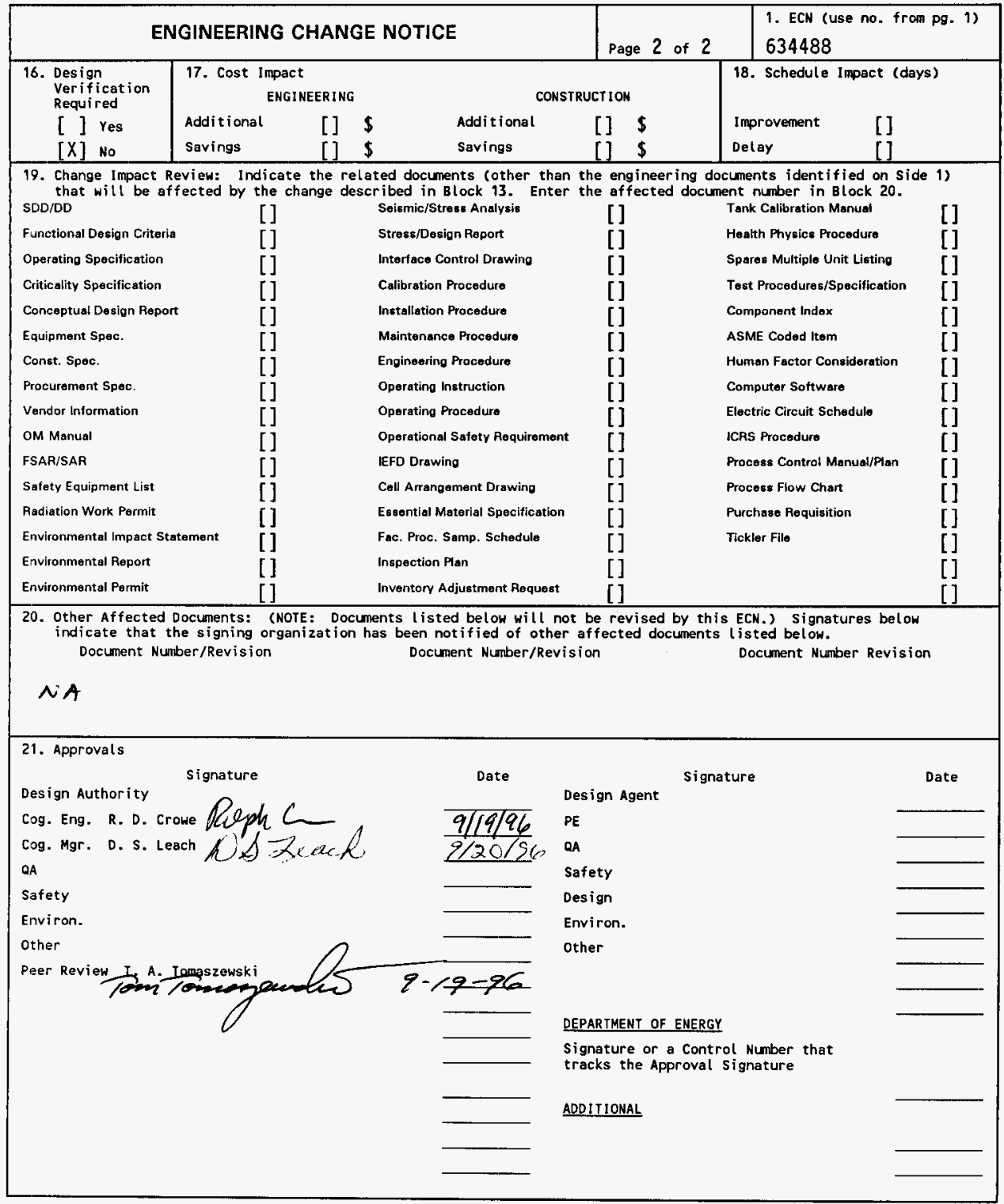




\section{CALCULATION NOTES THAT SUPPORT ACCIDENT SCENARIO AND CONSEQUENCE OF THE IN-TANK FUEL FIRE/DEFLAGERATION.}

Ralph D. Crowe

Westinghouse Hanford Company, Richland, WA 99352

U.S. Department of Energy Contract DE-AC06-87RL10930

$\begin{array}{lll}\text { EDT/ECN: } & \text { UC: } 510 \\ \text { Org Code: } & 8 M 720 & \text { Charge Code: NIFWl } \\ \text { B\&R Code: } & \text { EW3120071 } & \text { Total Pages: }\end{array}$

Key Words: In-Tank Fuel Fire/Deflageration, FSAR, and Safety Analysis

Abstract: The purpose of this calculation note is to provide the basis for In-Tank Fuel Fire/Deflageration consequence for the Tank Farm Safety Aanlysis Report (FSAR). Tank Fuel Fire/Deflageration scenario is developed and details and description of the analys is methods are provided.

TRADEMARK DISCLAIMER. Reference herein to any specific commercial product, process, or service by trade name, trademark, manufacturer, or otherwise, does not necessarily constitute or imply its endorsement, recommendation, or favoring by the United States Government or any agency thereof or its contractors or subcontractors.

Printed in the United States of America. To obtain copies of this document, contact: WHC/BCS Document Control Services, P.O. Box 1970, Mailstop H6-08, Richland WA 99352, Phone (509) 372-2420; Fax (509) 376-4989.
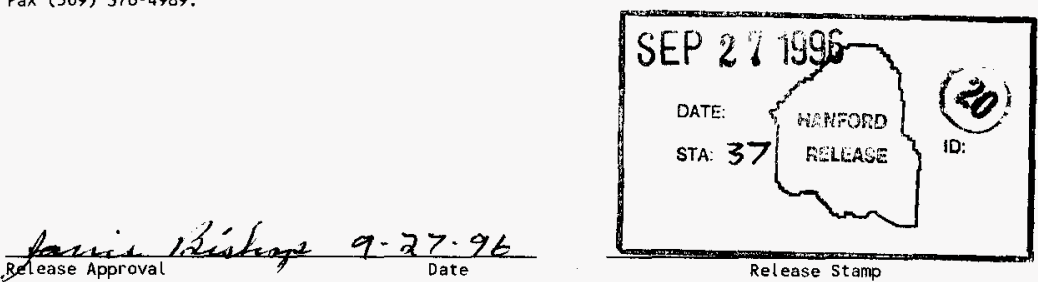

Approved for Public Release 
RECORD OF REVISION

(1) Document Number

WHC-SD-WM-CN-059

Page ]

(2) Title

Calculation Note that Supports Accident Scenario and Consequence Determination of the In-Tank Fuel Fire/Deflagration.

CHANGE CONTROL RECORD

\begin{tabular}{|l|l|}
\hline (3) Revision & (4) Description of Change - Replace, Add, and Delete Pages \\
\hline 0 & (7) Original issue (EDT 618485) \\
\hline 1 RS & Replace (ECN 634488) \\
\hline
\end{tabular}

\begin{tabular}{|l|l|}
\hline \multicolumn{2}{|c|}{ Authorized for Release } \\
\hline (5) Cog. Engr. & (6) Cog. Mgr. Date \\
\hline R.D. Crowe & D.S. Leach \\
\hline R.D. PCFowe & D.S. Leach OAJ \\
\hline $720 / 96$ & \\
\hline & \\
\hline & \\
\hline
\end{tabular}

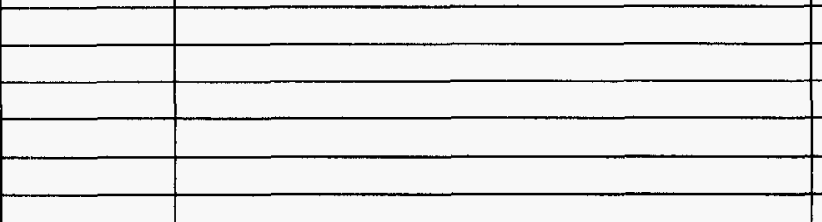




\title{
Calculation Notes that Support Accident Scenario and Consequence Determination of the In-Tank Fuel Fire/Deflagration
}

\author{
Ralph Crowe \\ Nuclear Analysis and Characterization
}

\section{Purpose}

Diesel and gasoline powered vehicles routinely enter the tank farms in support of surveillance, sampling, maintenance and construction activities. A hazards analysis identified the potential of these vehicles to be involved in an accident resulting in fuel from a ruptured vehicle tank spilling into a waste storage tank and igniting. Several possible scenarios can be considered in assessing the results of fuel spills from vehicles. A distinction is made between a pool fire where the vehicle fuel burns on the surface of the waste and a headspace deflagration where head space volume reaches the lower flammability limit (LFL) from the vaporized fuel and then is ignited.

This analysis identifies the consequences for both a pool fire on the surface of the waste and a deflagration in the headspace by showing these accidents are bounded by the Organic Solvent Fire Accident (Cowley 1996) and SST and DST Flammable Gas Deflagration Accidents (Van Vleet 1996).

\section{Scenario Development}

The following paragraphs develop the scenario for a vehicle fuel fire in single shell tanks (SSTs), double shell tank (DSTs), double-shell tank annulus, and miscellaneous other tanks including the double-contained receiver tanks (DCRTs), 200-series single shell tanks, catch tanks and MISFs.

The In-Tank Fuel Fire/Deflagration accident is initiated by an errant vehicle or truck (external event) that shears off one or more tank risers. The vehicle fuel tank is ruptured and its contents released. A portion of the fuel enters the waste tank through the damaged riser and/or through cracks in the cover blocks above the pump pit. Some of the vehicle fuel vaporizes or is aerosolized as the fuel drains to the tank. The remaining portion of the fuel pools on the waste surface. The fuel spill has the potential to cause a fire or deflagration in the head space of the tank and could challenge the active or passive ventilation systems. A deflagration could also damage the structural integrity of the tank with the potential for collapse of the tank dome. The uncontrolled release of gases, aerosols, and particulate of radioactive and hazardous material from the tank head space, ventilation system and the tank waste would result.

\section{Unmitigated Accidents}

Vehicle fuel pool fire in waste tank - The spilled vehicle fuel enters the waste tank but the vehicle fuel is not immediately ignited. The fuel pools on the surface of the waste and vaporizes. However, the fuel is ignited before the lower flammability limit is reached in the head space. The fuel burns as a pool fire. This scenario is bounded by the Organic Solvent Fire accident (Cowley 1996) based in terms of amount of fuel burned.

Vehicle fuel deflagration in the headspace - A portion of the spilled fuel enters the waste tank and is not immediately ignited. The fuel pools on the surface of the waste and begins to vaporize. The lower flammability limit is reached and the vaporized fuel ignites in the head space. This scenario is bounded by the Flammable Gas Deflagrations (Van Vleet 1996) based on the peak pressure of the burn. 


\section{Mitigated Accident}

The following controls have been selected to prevent this accident from occuring, thereby protecting the offsite public, onsite and facility worker.

- Vehicle fuel tank protection required within the tank farm boundary

- Physical barriers around tank farm above ground structures outside the tank farm

boundary;

only vehicles with fuel tank protection access inside the barrier.

\section{Input Data}

Gasoline Properties (Lange 1961) LFL : : 1.3.\%

gasoline has a specific gravity of $0.75 \rho_{\mathrm{H} 2 \mathrm{O}}:=1000 \cdot \frac{\mathrm{kg}}{\mathrm{m}^{3}} \quad \rho_{\text {liquid }}:=0.75 \cdot \rho_{\mathrm{H} 2 \mathrm{O}} \quad \rho_{\text {liquid }}=750 \cdot \frac{\mathrm{kg}}{\mathrm{m}^{3}}$

gasoline vapor is $3-4$ times heavier

than air (Lange 1961)

$$
\rho_{\text {air }}:=1.2 \cdot \frac{\mathrm{kg}}{\mathrm{m}^{3}} \quad \rho_{\text {gas }}:=3 \cdot \rho_{\text {air }} \quad \rho_{\text {gas }}=3.6 \cdot \frac{\mathrm{kg}}{\mathrm{m}^{3}}
$$

gallons of liquid gasoline per cubic meter of head space to reach the LFL

$$
\mathrm{f}_{\mathrm{LFL}}:=\mathrm{LFL} \cdot \frac{\rho_{\text {gas }}}{\rho_{\text {liquid }}} \quad \mathrm{f}_{\mathrm{LFL}}=\mathbf{1 . 6 4 8 \cdot 1 0 ^ { - 2 }} \cdot \frac{\text { gal }}{\mathrm{m}^{3}}
$$

\begin{tabular}{|c|c|c|c|c|c|c|c|}
\hline 530,000 gallon capacity; & \multicolumn{3}{|c|}{$\begin{array}{l}630,000 \text { gallon capacity; } \\
758,000 \text { gallon capacity; }\end{array}$} & Dish bottom; & \multicolumn{3}{|c|}{$114,400 \mathrm{ft}^{3}$ empty $-\mathrm{B}, \mathrm{BX}, \mathrm{C}$} \\
\hline SST, & \multicolumn{3}{|c|}{$1,000,000$ gallon capacity; } & ish bottom; & \multicolumn{3}{|c|}{; $170,620 \mathrm{ft}^{3}$ empty - $\mathbf{5 x}$ tanks } \\
\hline $\begin{array}{l}\text { SST, } \\
\text { OST's }\end{array}$ & \multicolumn{3}{|c|}{$\begin{array}{l}1,000,000 \text { gallon capacity; } \\
1,160,000 \text { gallon capacity; }\end{array}$} & $\begin{array}{l}\text { lat bottom; } \\
\text { lat bottom; }\end{array}$ & \multicolumn{3}{|c|}{$\begin{array}{l}168,949 \mathrm{ft}^{3} \text { empty - A, AX tan } \\
187,976 \mathrm{ft}^{3} \text { empty - AN, AP, A }\end{array}$} \\
\hline ank & $\begin{array}{l}\text { Tank } \\
\text { Radius }\end{array}$ & $\begin{array}{l}\text { Tank } \\
\text { Capacity }\end{array}$ & $\begin{array}{l}\text { Operatin } \\
\text { Volume }\end{array}$ & $\begin{array}{l}\text { g Total } \\
\text { Type }\end{array}$ & $\begin{array}{l}\text { Bottom } \\
\text { Meight }\end{array}$ & $\begin{array}{l}\text { Capacity } \\
\text { Volume }\end{array}$ & (Galfin) \\
\hline arm & (ft) & (gals) & $\left(\mathrm{ft}^{3}\right)$ & & (in) & (gals) & \\
\hline b & 37.5 & 530,000 & 114,400 & dished & 0 & 12,500 & 2,754 \\
\hline & 37.5 & 630,000 & 114,400 & dished & 0 & 12,500 & 2,754 \\
\hline c & 37.5 & 530,000 & 114,400 & dished & o & 12,500 & 2,754 \\
\hline & 37.6 & 530,000 & 114,400 & dished & $\mathbf{0}$ & 12,500 & 2,754 \\
\hline $\begin{array}{l}\text { u } \\
\text { by }\end{array}$ & $\begin{array}{l}37.5 \\
37.5\end{array}$ & $\begin{array}{l}530,000 \\
758,000\end{array}$ & $\begin{array}{l}114,400 \\
140,600\end{array}$ & $\begin{array}{l}\text { dished } \\
\text { dished }\end{array}$ & $\begin{array}{r}0 \\
12\end{array}$ & $\begin{array}{l}12,500 \\
12,500\end{array}$ & $\begin{array}{l}2,754 \\
2,754\end{array}$ \\
\hline $\begin{array}{l}s \\
t x\end{array}$ & $\begin{array}{l}37.5 \\
37.5\end{array}$ & $\begin{array}{l}758,000 \\
758,000\end{array}$ & $\begin{array}{l}140,600 \\
140,600\end{array}$ & $\begin{array}{l}\text { dished } \\
\text { dished }\end{array}$ & $\begin{array}{l}12 \\
12\end{array}$ & $\begin{array}{l}12,500 \\
12,500\end{array}$ & $\begin{array}{l}2,754 \\
2,754\end{array}$ \\
\hline ty & 37.5 & 758,000 & 140,600 & dished & 12 & 12,500 & 2,754 \\
\hline$s x$ & 37.5 & $1,000,000$ & 170,620 & dished & 12 & 18,500 & 2,754 \\
\hline a & 37.5 & $1,000,000$ & 168,949 & flat & 0 & 0 & 2,754 \\
\hline & 37.5 & $1,000,000$ & 168,949 & flat & 0 & 0 & 2,754 \\
\hline & 37.6 & $1,160,000$ & 188,490 & flat & 0 & 0 & 2,754 \\
\hline & 37.5 & $1,160,000$ & 188,490 & flat & 0 & 0 & 2,754 \\
\hline$w$ & 37.6 & $1,160,000$ & 188,490 & flat & 0 & 0 & 2,754 \\
\hline & 37.5 & $1,160,000$ & 188,490 & flat & 0 & 0 & 2,754 \\
\hline & 37.5 & $1,000,000$ & 188,490 & flat & 0 & 0 & 2,754 \\
\hline & 37.5 & $1,000,000$ & 188,490 & flat & 0 & 0 & 2,754 \\
\hline b2 & 10 & 55,000 & 8,168 & dished & 6 & 590 & 196 \\
\hline & 10 & 55,000 & 8,168 & dished & 6 & 590 & 196 \\
\hline & 10 & 56,000 & 8,168 & dished & 6 & 590 & 196 \\
\hline 42 & 10 & 55,000 & 8,168 & dished & 6 & 590 & 196 \\
\hline
\end{tabular}

Table 1 - Tank Capacity by tank type and farm (Hopkins, 1995) 


\section{Calculations for Pool Fire -}

The amount of diesel or gasoline fuel is limited to 60 gallons for the vehicle fuel pool fire in waste tank (see attached IVF). This accident is directly comparable to the organic solvent fire in the waste tank (Cowley 1996). The organic solvent fire, which is based on dodecane, is oxygen limited. The stoichiometry of burning either dodecane or diesel fuel should be nearly the same (see attached memo). Therefore, both the dodecane and diesel fires are expected to self extinguish when the oxygen concentration is approximately 13 mole percent.

The largest pressure transient and greatest consequences for the organic pool accident involved a fire that burned $146 \mathrm{kgs}$ of solvent before the fire self extinguished. This fire was based on a pool surface of $210 \mathrm{~m}^{2}$. Using a specific gravity of 0.75 for diesel fuel and a density of $1000 \mathrm{~kg} / \mathrm{m}^{3}$ for water, $146 \mathrm{kgs}$ of solvent is equivalent to 51 gallons of diesel fuel. However, the pool surface of the fuel burn would be less since 60 gallons of fuel would have a depth of only $0.1 \mathrm{~cm}$ if spread out over $210 \mathrm{~m}^{2}$.

$$
\frac{146 \cdot \mathrm{kg}}{0.75 \cdot 1000 \cdot \frac{\mathrm{kg}}{\mathrm{m}^{3}}}=51.4 \cdot \mathrm{gal} \quad \frac{60 \cdot \mathrm{gal}}{210 \cdot \mathrm{m}^{2}}=0.1 \cdot \mathrm{cm}
$$

\section{Calculations for Deflagration -}

The peak pressure from a gasoline burn is equivalent to a hydrogen burn. The following discussion supporting this argument is condensed from the Closed Vessel Deflagration description of the reference (NFPA 1988).

Conservative estimates of the associated pressure rise in a closed vessel can be made from flame temperature calculations as follows. The ratio of the peak pressure to initial pressure can be calculated from the ideal gas equations at the end of the combustion and prior to ignition.

$$
\frac{\mathrm{P}_{\mathrm{m}}}{\mathrm{P}_{0}}=\frac{\mathrm{M}_{0}}{\mathrm{M}_{\mathrm{b}}} \cdot \frac{\mathrm{T}_{\mathrm{b}}}{\mathrm{T}_{0}}
$$

where:

$$
\begin{aligned}
& P_{m}=\text { maximum pressure at completion of burn } \\
& P_{0}=\text { initial pressure } \\
& M_{0}=\text { molecular weight of gas-air mixture } \\
& M_{b}=\text { molecular weight of combustion products } \\
& T_{b}=\text { temperature of burned gas } \\
& T_{0}=\text { initial temperature }
\end{aligned}
$$

Assuming the deflagration occurs sufficiently fast to neglect heat dissipation, the value of $T_{b}$ should correspond to the adiabatic flame temperature of the gas-air mixture. Adiabatic constant-pressure temperatures are shown in the attached figure (Figure 2.5.4 from NFPA 1988) for an number of fuel-air mixtures. The temperatures shown in the figure are in the range of $2100 \mathrm{~K}$ to $2400 \mathrm{~K}$ for most of the hydrocarbon gases-air mixtures. The adiabatic constant-volume temperatures are generally about $10 \%$ higher than the corresponding constant-pressure temperatures.

The molecular weights needed for the above equation are approximately the same prior to and following the combustion for many of the gas-air mixtures. An exception is hydrogen where the molecular weight of the of the combustion products is less than the initial gas-air mixture by about $15 \%$ for a stoichmetric mix. For non-stoichmetric mixes, this difference becomes less. 
Therefore, the use of the equation would indicate peak/initial pressure ratios of 7 to 8 range for both hydrogen and the heavier hydrocarbons initially at $300 \mathrm{~K}$. Use of the constant-volume adiabatic flame temperature and accurate calculations of mixture molecular weights would probably produce pressure ratios about 10 percent higher for many of the mixtures.

The burning velocity, $S_{u}$, is the flame propagation velocity relative to the unburned gas. The burning velocity for hydrogen is about 8 times the velocity of the heavier hydrocarbons. This means that the rate of pressure rise for a hydrogen burn would be greater than for a gasoline burn (NFPA 1998).

\section{Quantity of Gasoline Required to Reach the LFL in Various Tanks}

The lower flammable limit (LFL) can be reached in a full DST (416 inches) with $\mathbf{1 6 . 3}$ gallons of fuel. The annulus of the DST reaches the LFL at 9.9 gallons.

DSTs - (AN, AP, AW, SY, AY, AZ farms)

Estimated 16.3 gallons of gasoline to reach the LFL in full DST.

$$
\begin{aligned}
& \text { DST_radius }:=\mathbf{3 7 . 5} \text { flarea }:=\pi \cdot D_{\text {DST_radius }}{ }^{2} \quad \text { area }=\mathbf{4 1 0} \cdot \mathrm{m}^{2} \\
& \text { empty }:=187976 \cdot \mathrm{ft}^{3} \quad \text { empty }=5323 \cdot \mathrm{m}^{3} \\
& \max \text { height }=416 \cdot \text { in } \quad \max \text { height }=10.6 \cdot \mathrm{m} \\
& \text { head_space }:=\text { empty }-\left(\max \_ \text {height } \cdot \text { area }\right) \quad \text { head_space }=986 \cdot \mathrm{m}^{3} \\
& \text { head_space } \cdot f_{L F L}=16.3 \cdot \mathrm{gal} \quad(\text { empty }-(161.5 \cdot \text { in } \cdot \text { area })) \cdot f_{L F L}=60 \cdot \mathrm{gal}
\end{aligned}
$$

DST Annulus (AN, AP, AW, SY, AY, AZ farms)

Width of annulus estimated to be approximately $\mathbf{2 . 5} \mathrm{ft}$ with a height of $420 \mathrm{in}$.

Estimated 9.9 gallons of gasoline to reach the LFL in the DST annulus.

$$
\begin{aligned}
& \text { annulus : }=\left[\left[(37.5 \cdot \mathrm{ft}+2.5 \cdot \mathrm{ft})^{2}-(37.5 \cdot \mathrm{ft})^{2}\right] \cdot \pi\right] \cdot 420 \cdot \mathrm{in} \\
& \text { annulus }=603 \cdot \mathrm{m}^{3} \quad \text { annulus } \cdot \mathrm{f}_{\mathrm{LFL}}=9.9 \cdot \mathrm{gal}
\end{aligned}
$$

SSTs - (A, B, BX, BY, C, S, SX, T, TX, TY, U Farms)

Since transfers to a SST is not allowed, the existing waste volume in each SST will not increase. Based on published waste volumes (Hanlon, 1995), the quantity of fuel required to reach the LFL was calculated for each SST in the following manner as done below for A-101. The results are given in table 2.

Estimated 19.4 gallons of gasoline to reach LFL in tank 241-A-101

$$
\begin{aligned}
& \text { empty_volume }:=168949 \cdot \mathrm{ft}^{3} \\
& \text { waste_volume }:=953 \cdot \mathrm{kgal}
\end{aligned}
$$$$
\text { empty_volume }=4784 \cdot \mathrm{m}^{3}
$$$$
\text { waste_volume }=3607 \cdot \mathrm{m}^{3}
$$

$$
\text { (empty_volume - waste_volume) } \cdot \mathrm{f}_{\mathrm{LFL}}=19.4 \cdot \mathrm{gal}
$$


There are 115 SST tanks identified where the head space could reach the LFL with 60 gallons of diesel or gasoline fuel. None of these 110 tanks have vapor space temperatures that exceed the flashpoint of diesel fuel. The flash point of Grade 2D-A, general purpose automotive diesel fuel is $125 \mathrm{~F}$ (Lange 1961). Only the six tanks in the $S X$ farm (241-SX-101 through 241-SX-106) on active ventilation could potentially exceed the flashpoint temperature and reach the LFL with 60 gallons of diesel fuel if ventilation were lost for some sufficient length of time.

DCRTs, 200-series single shell tanks, and catch tanks even when empty reach the LFL with less then 25 gallons of gasoline, i.e, 20 foot diameter single shell tanks with 55,000 gal capacity (Hopkins, 1995).

$$
\begin{aligned}
& \text { volume }_{\text {SST200 }}:=\mathbf{5 5 0 0 0} \cdot \mathrm{gal} \\
& \text { volume }_{\mathrm{SST} 200^{\circ}} \mathrm{LFL}=\mathbf{3 . 4} \cdot \mathrm{gal}
\end{aligned}
$$

Estimated 3.4 gallons of gasoline to reach the LFL in an empty $20 \mathrm{ft}$ diameter single shell tanks (Farms B,C,T \& U). A full tank would require even less fuel.

\section{Note}

This report was written in MathCad Plus 6.0 Professional Edition (Maftsoft 1995). The following constants and/or equations were used as a part of the calculation.

$$
\text { kgal }=\mathbf{1 0 0 0} \cdot \text { gal }
$$

\section{References}

Cowley, W. L., 1996, Consequences of Postulated Solvent Fires in Hanford Site Tanks, WHC-SD-WM-CN-032, Westinghouse Hanford Company, Richland, Washington.

Hopkins, J. D., 1995, Methodology For Flammable Gas Evaluations, WHC-SD-WM-TI-724, Westinghouse Hanford Company, Richland, Washington.

Lange, 1961, Handbook of Chemistry,McGraw-Hill Book Company, Inc., New York, New York.

NFPA, 1988, The SFPE Handbook of Fire Protection Engineering, National Fire Protection Association, Quicy, Massachusetts.

Van Vleet, R. J., 1996, Flammable Gas Deflagration Consequence Calculations for the Tank Waste Remediation Systems Basis for interim Operation, WHC-SD-WM-CN-055, Westinghouse Hanford Company, Richland, Washington. 
Table 2 - Single Shell Lower Flammability Limit Calculations

\begin{tabular}{|c|c|c|c|c|c|c|}
\hline Tank & $\begin{array}{l}\text { Tank } \\
\text { Capacity } \\
\text { gal }\end{array}$ & $\begin{array}{l}\text { Empty } \\
\text { Volume } \\
\mathrm{ft}^{\wedge} 3\end{array}$ & $\begin{array}{l}\text { Waste } \\
\text { Volume } \\
\text { kgal }\end{array}$ & $\begin{array}{l}\text { Vapor } \\
\text { space } \\
m^{\wedge} 3\end{array}$ & $\begin{array}{l}\text { LFL } \\
\text { gal }\end{array}$ & $\begin{array}{l}\text { Average } \\
\text { Vapor } \\
\text { Space } \\
\text { Temp } \\
\text { F }\end{array}$ \\
\hline A-101 & $1,000,000$ & 168,949 & 953 & 1,177 & 19.4 & 99 \\
\hline$A-102$ & $1,000,000$ & 168,949 & 41 & 4,629 & 76.3 & 90 \\
\hline A-103 & $1,000,000$ & 168,949 & 370 & 3,384 & 55.8 & 86 \\
\hline A-104 & $1,000,000$ & 168,949 & 28 & 4,678 & 77.1 & 193 \\
\hline A-106 & $1,000,000$ & 168,949 & 125 & 4,311 & 71.1 & 106 \\
\hline$A X-101$ & $1,000,000$ & 168,949 & 748 & 1,953 & 32.2 & 90 \\
\hline AX-102 & $1,000,000$ & 168,949 & 39 & 4,636 & 76.4 & 76 \\
\hline AX-103 & $1,000,000$ & 168,949 & 112 & 4,360 & 71.9 & 90 \\
\hline AX-104 & $1,000,000$ & 168,949 & 7 & 4,758 & 78.4 & 94 \\
\hline B-10t & 500,000 & 114,400 & 113 & 2,812 & 46.3 & 92 \\
\hline B-102 & 500,000 & 114,400 & 32 & 3,118 & 51.4 & 64 \\
\hline B-103 & 500,000 & 114,400 & 59 & 3,016 & 49.7 & 62 \\
\hline B-104 & 500,000 & 114,400 & 371 & 1,835 & 30.2 & 63 \\
\hline B-105 & 500,000 & 114,400 & 306 & 2,081 & 34.3 & 63 \\
\hline B-106 & 500,000 & 114,400 & 117 & 2,797 & 46.1 & 62 \\
\hline B-107 & 500,000 & 114,400 & 165 & 2,615 & 43.1 & 62 \\
\hline B-108 & 500,000 & 114,400 & 94 & 2,884 & 47.5 & 62 \\
\hline B-109 & 500,000 & 114,400 & 127 & 2,759 & 45.5 & 61 \\
\hline B-110 & 500,000 & 114,400 & 246 & 2,308 & 38.0 & 68 \\
\hline B-111 & 500,000 & 114,400 & 237 & 2,342 & 38.6 & 86 \\
\hline B-112 & 500,000 & 114,400 & 33 & 3,115 & 51.3 & 63 \\
\hline$B X-101$ & 500,000 & 114,400 & 42 & 3,080 & 50.8 & 64 \\
\hline$B X-102$ & 500,000 & 114,400 & 96 & 2,876 & 47.4 & 65 \\
\hline$B X-103$ & 500,000 & 114,400 & 66 & 2,990 & 49.3 & 77 \\
\hline BX-104 & 500,000 & 114,400 & 99 & 2,865 & 47.2 & 87 \\
\hline$B X-104$ & 500,000 & 114,400 & 99 & 2,865 & 47.2 & 72 \\
\hline$B X-105$ & 500,000 & 114,400 & 51 & 3,046 & 50.2 & 66 \\
\hline$B X-106$ & 500,000 & 114,400 & 31 & 3,122 & 51.5 & 63 \\
\hline$B X-107$ & 500,000 & 114,400 & 345 & 1,933 & 31.9 & 72 \\
\hline BX-108 & 500,000 & 114,400 & 26 & 3,141 & 51.8 & 65 \\
\hline BX-109 & 500,000 & 114,400 & 193 & 2,509 & 41.4 & 75 \\
\hline$B X-110$ & 500,000 & 114,400 & 198 & 2,490 & 41.0 & 63 \\
\hline BX-111 & 500,000 & 114,400 & 211 & 2,441 & 40.2 & 65 \\
\hline$B X-112$ & 500,000 & 114,400 & 165 & 2,615 & 43.1 & 65 \\
\hline
\end{tabular}


Table 2 - Single Shell Lower Flammability Limit Calculations (Continued)

\begin{tabular}{|c|c|c|c|c|c|c|}
\hline Tank & $\begin{array}{l}\text { Tank } \\
\text { Capacity } \\
\text { gal }\end{array}$ & $\begin{array}{l}\text { Empty } \\
\text { Volume } \\
\mathrm{ft}^{\wedge} 3\end{array}$ & $\begin{array}{l}\text { Waste } \\
\text { Volume } \\
\text { kgal }\end{array}$ & $\begin{array}{l}\text { Vapor } \\
\text { space } \\
m^{\wedge} 3\end{array}$ & $\begin{array}{l}\text { LFL } \\
\text { gal }\end{array}$ & $\begin{array}{l}\text { Average } \\
\text { Vapor } \\
\text { Space } \\
\text { Temp } \\
\text { F }\end{array}$ \\
\hline BY-101 & 750,000 & 140,600 & 387 & 2,516 & 41.5 & 66 \\
\hline BY-102 & 750,000 & 140,600 & 341 & 2,691 & 44.4 & 76 \\
\hline BY-103 & 750,000 & 140,600 & 400 & 2,467 & 40.7 & 70 \\
\hline BY-104 & 750,000 & 140,600 & 406 & 2,444 & 40.3 & 79 \\
\hline BY-105 & 750,000 & 140,600 & 503 & 2,077 & 34.2 & 78 \\
\hline BY-106 & 750,000 & 140,600 & 642 & 1,551 & 25.6 & 81 \\
\hline BY-107 & 750,000 & 140,600 & 266 & 2,974 & 49.0 & 79 \\
\hline BY-108 & 750,000 & 140,600 & 228 & 3,118 & 51.4 & 80 \\
\hline BY-109 & 750,000 & 140,600 & 423 & 2,380 & 39.2 & 60 \\
\hline BY-110 & 750,000 & 140,600 & 398 & 2,475 & 40.8 & 74 \\
\hline BY-111 & 750,000 & 140,600 & 459 & 2,244 & 37.0 & 70 \\
\hline BY-112 & 750,000 & 140,600 & 291 & 2,880 & 47.5 & 72 \\
\hline C-101 & 500,000 & 114,400 & 88 & 2,906 & 47.9 & 85 \\
\hline C-102 & 500,000 & 114,400 & 423 & 1,638 & 27.0 & 90 \\
\hline C-103 & 500,000 & 114,400 & 195 & 2,501 & 41.2 & 105 \\
\hline C-104 & 500,000 & 114,400 & 295 & 2,123 & 35.0 & 86 \\
\hline C-105 & 500,000 & 114,400 & 150 & 2,672 & 44.0 & 83 \\
\hline C-106 & 500,000 & 114,400 & 229 & 2,373 & 39.1 & 80 \\
\hline C-107 & 500,000 & 114,400 & 275 & 2,198 & 36.2 & 109 \\
\hline C-108 & 500,000 & 114,400 & 66 & 2,990 & 49.3 & 73 \\
\hline C-109 & 500,000 & 114,400 & 62 & 3,005 & 49.5 & 76 \\
\hline C-110 & 500,000 & 114,400 & 187 & 2,532 & 41.7 & 65 \\
\hline C-111 & 500,000 & 114,400 & 57 & 3,024 & 49.8 & 74 \\
\hline C-112 & 500,000 & 114,400 & 104 & 2,846 & 46.9 & 77 \\
\hline S-101 & 750,000 & 140,600 & 427 & 2,365 & 39.0 & 91 \\
\hline S-102 & 750,000 & 140,600 & 549 & 1,903 & 31.4 & 77 \\
\hline S-103 & 750,000 & 140,600 & 248 & 3,043 & 50.2 & 71 \\
\hline S-104 & 750,000 & 140,600 & 294 & 2,868 & 47.3 & 84 \\
\hline S-105 & 750,000 & 140,600 & 456 & 2,255 & 37.2 & 66 \\
\hline S-106 & 750,000 & 140,600 & 543 & 1,926 & 31.7 & 66 \\
\hline S-107 & 750,000 & 140,600 & 368 & 2,588 & 42.7 & 80 \\
\hline S-108 & 750,000 & 140,600 & 604 & 1,695 & 27.9 & 67 \\
\hline S-109 & 750,000 & 140,600 & 568 & 1,831 & 30.2 & 76 \\
\hline S-110 & 750,000 & 140,600 & 390 & 2,505 & 41.3 & 76 \\
\hline S-111 & 750,000 & 140,600 & 596 & 1,725 & 28.4 & 72 \\
\hline S-112 & 750,000 & 140,600 & 637 & 1,570 & 25.9 & 67 \\
\hline
\end{tabular}


WHC-SD-WM-CN-059, Rev. 1

Table 2 - Single Shell Lower Flammability Limit Calculations (Continued)

\begin{tabular}{|c|c|c|c|c|c|c|}
\hline Tank & $\begin{array}{l}\text { Tank } \\
\text { Capacity } \\
\text { gal }\end{array}$ & $\begin{array}{l}\text { Empty } \\
\text { Volume } \\
\mathrm{ft}^{\wedge} 3\end{array}$ & $\begin{array}{l}\text { Waste } \\
\text { Volume } \\
\text { kgal }\end{array}$ & $\begin{array}{l}\text { Vapor } \\
\text { space } \\
m^{\wedge} 3\end{array}$ & $\begin{array}{l}\text { LFL } \\
\text { gal }\end{array}$ & $\begin{array}{l}\text { Average } \\
\text { Vapor } \\
\text { Space } \\
\text { Temp } \\
\text { F }\end{array}$ \\
\hline sX-101 & $1,000,000$ & 170,620 & 458 & 3,098 & 51.1 & 91 \\
\hline sX-102 & $1,000,000$ & 170,620 & 543 & 2,776 & 45.8 & 91 \\
\hline $5 x-103$ & $1,000,000$ & 170,620 & 652 & 2,363 & 39.0 & 116 \\
\hline $5 x-104$ & $1,000,000$ & 170,620 & 614 & 2,507 & 41.3 & 85 \\
\hline sX-105 & $1,000,000$ & 170,620 & 583 & 2,625 & 43.3 & 86 \\
\hline $5 X-106$ & $1,000,000$ & 170,620 & 538 & 2,795 & 46.1 & 82 \\
\hline sX-107 & $1,000,000$ & 170,620 & 104 & 4,438 & 73.2 & 121 \\
\hline SX-107 & $1,000,000$ & 170,620 & 104 & 4,438 & 73.2 & 113 \\
\hline SX-108 & $1,000,000$ & 170,620 & 115 & 4,396 & 72.5 & 134 \\
\hline SX-108 & $1,000,000$ & 170,620 & 115 & 4,396 & 72.5 & 132 \\
\hline sX-109 & $1,000,000$ & 170,620 & 250 & 3,885 & 64.0 & 124 \\
\hline sx-110 & $1,000,000$ & 170,620 & 62 & 4,597 & 75.8 & 115 \\
\hline$s x-111$ & $1,000,000$ & 170,620 & 125 & 4,358 & 71.8 & 124 \\
\hline $5 x-112$ & $1,000,000$ & 170,620 & 92 & 4,483 & 73.9 & 122 \\
\hline sx-113 & $1,000,000$ & 170,620 & 26 & 4,733 & 78.0 & 74 \\
\hline $5 X-114$ & $1,000,000$ & 170,620 & 181 & 4,146 & 68.3 & 135 \\
\hline SX-115 & $1,000,000$ & 170,620 & 12 & 4,786 & 78.9 & \\
\hline$T-101$ & 500,000 & 114,400 & 102 & 2,853 & 47.0 & 68 \\
\hline $\mathrm{T}-102$ & 500,000 & 114,400 & 32 & 3,118 & 51.4 & 71 \\
\hline$T-102$ & 500,000 & 114,400 & 32 & 3,118 & 51.4 & 71 \\
\hline$T-103$ & 500,000 & 114,400 & 27 & 3,137 & 51.7 & 59 \\
\hline$T-104$ & 500,000 & 114,400 & 445 & 1,555 & 25.6 & 65 \\
\hline$T-104$ & 500,000 & 114,400 & 445 & 1,555 & 25.6 & 59 \\
\hline$T-105$ & 500,000 & 114,400 & 98 & 2,868 & 47.3 & 76 \\
\hline$T-105$ & 500,000 & 114,400 & 98 & 2,868 & 47.3 & 74 \\
\hline$T-106$ & 500,000 & 114,400 & 21 & 3,160 & 52.1 & 59 \\
\hline$T-107$ & 500,000 & 114,400 & 180 & 2,558 & 42.2 & 63 \\
\hline$T-108$ & 500,000 & 114,400 & 44 & 3,073 & 50.7 & 63 \\
\hline$T-109$ & 500,000 & 114,400 & 58 & 3,020 & 49.8 & 75 \\
\hline$T-109$ & 500,000 & 114,400 & 58 & 3,020 & 49.8 & 62 \\
\hline$T-110$ & 500,000 & 114,400 & 379 & 1,805 & 29.8 & 59 \\
\hline$T-111$ & 500,000 & 114,400 & 458 & 1,506 & 24.8 & 58 \\
\hline$T-112$ & 500,000 & 114,400 & 67 & 2,986 & 49.2 & 59 \\
\hline
\end{tabular}


Table 2 - Single Shell Lower Flammability Limit Calculations (Continued)

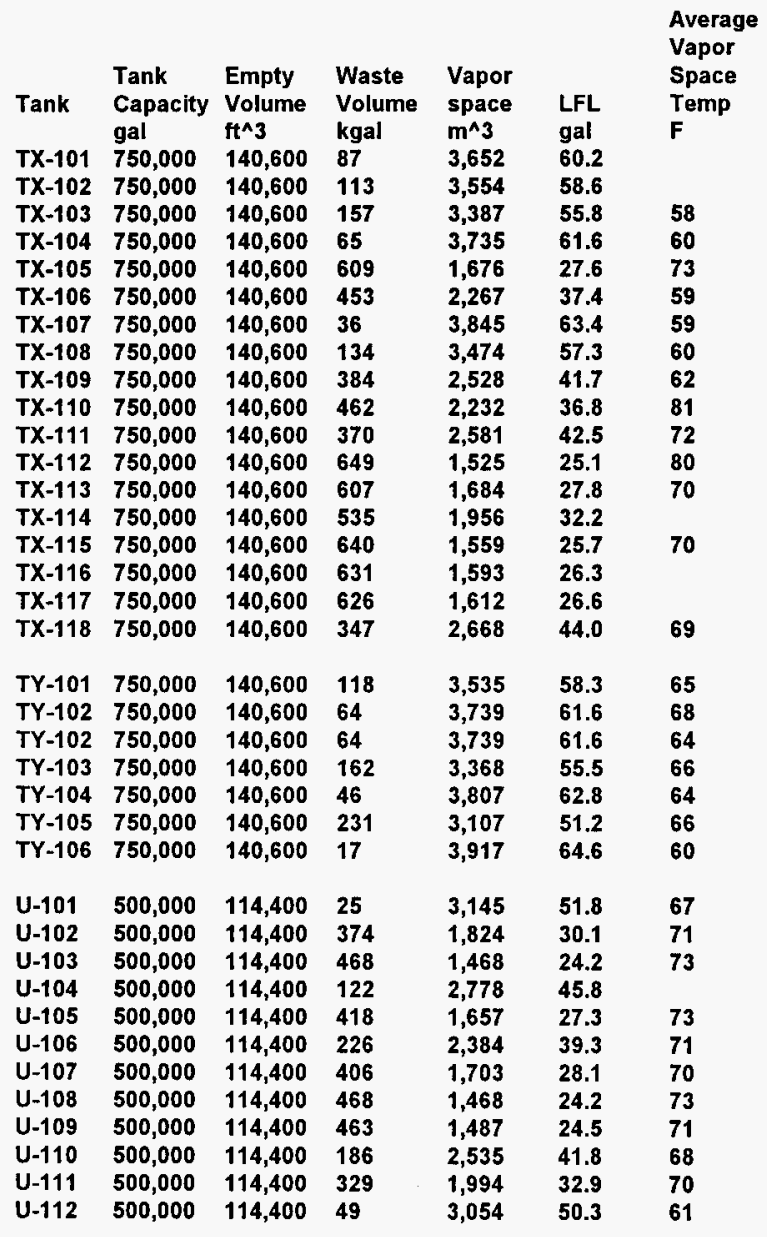




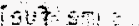

Tracking \# VEHFUEL-001

Name of Originator

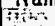

J. H. Grigsby

Organization or Team

ISB/FSAR
Date

$3 / 15 / 96$

Statement of Problem - The candidate accident "Vehicle Fuel Spill/Fire" involves a "run-away vehicle or truck that shears off one or more risers and ruptures the fuel tank. The resulting fire from the fuel spill has the potential to cause a fire or explosion in the headspace of the tank....". In order to perform

bounding/representative unmitigated accident cases, the following data is requested.

1. The maximum amount of gasoline contained in the vehicles that are allowed in the tank farms. The bounding assumption is that all of this fuel can enter a SST or DST or DST annulus and be ignited.

2. The maximum amount of diesel fuel contained in the vehicles that are allowed in the tank farms. The bounding assumption is that all of this fuel can enter a SST, a DST or DST annulus and be ignited.

3. Please specify the minimum ventilation flow rate in a DST and DST annulus. This ventilation may or may not.prevent a fuel vapor cloud from forming as is evaporates from the pool created by the fuel spilled into the tank. BEst judgement is thta unless the flowrate if quite high (hundreds of (FM), there is little chance of showing that a vapor cloud could not form above the fuel pool. I.e., if minimum flow rate is in the 20 - $50 \mathrm{CFM}$ range, don't spend much time being more accurate.

4. Please specify the maximum temperature that you desire DSTs to be limited to. If it is above $55-70^{\circ} \mathrm{C}$, don't spend much time on this one either as we will need to assume that the fuels will be well above their flashpoints (diesel has a flashpoint of $40-55^{\circ} \mathrm{C}$ )

5. Please verify that a vehicle accident and spill can not cause fuel to enter DCRTs, catch tanks, or MISFs. If this can not be verified, we will assume that fuel can enter these tanks. Therefore, please specify the maximum temperatures for these tanks. Agajn, if it is above $55-70^{\circ} \mathrm{C}$, just so state and the exact maximum is not that important.

\begin{tabular}{|l|l|l|l|}
\hline Alternatives & Consequences to Alternatives \\
\hline & & Basis for Decision \\
\hline Decision Reached & & \\
\hline Date Requested: 3/15/96 & Sent To: Tim Bohan & Date Requested By: 3/22/96 \\
\hline
\end{tabular}


Response \#1 $60 \mathrm{galions}$ is a good bounding number for diesel and gasoline fuel. The maximum temperature for DSTs should be limited to less than $200 \mathrm{deg}$. F. Assume fuel can enter the DCRTs. Assume less than $200 \mathrm{deg}$. F for DCRTs also; since the waste will is not intended to be stored in DCRTs; we can assume the DST temp. is bounding. The design flow rates for the DST s are as follows: AW Primary 1000 SCFM, AW Annulus 4800 . SCFM, AN Primary 600 SCFM, AN Annulus 6125 SCFM, SY Primary 1000 CFM, SY Annulus $1000 \mathrm{CFM}$. The $A Y$ and $A Z$ farms use the same ventilation system, as such the Primary operates $800-1000 \mathrm{cfm}$, the stacked was measured at $3200-4000 \mathrm{cfm}$. The AY annulus ventilation systems (two separate ones) normally operate at $800 \mathrm{cfm}$; there maximum flow rate is approximately $3500 \mathrm{cfm}$. The $A Z^{-}$annulus ventilation pulls approximately $1600 \mathrm{cfm}$ through each annuli.

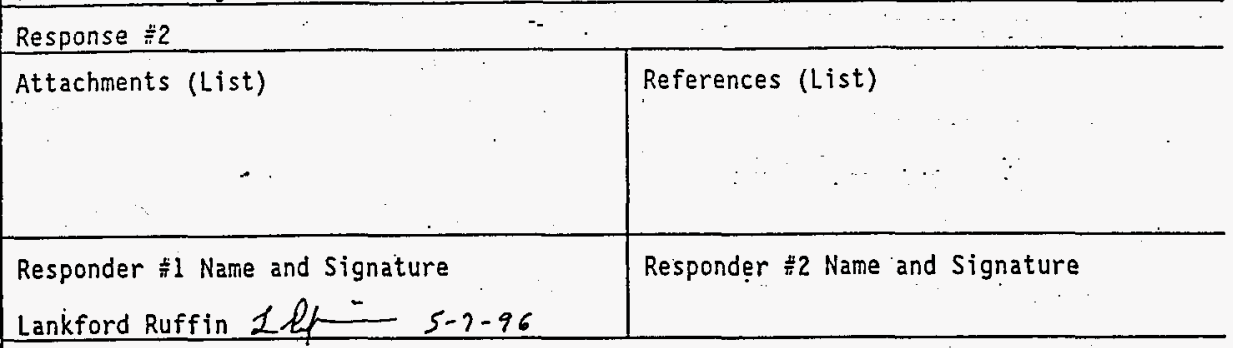

POC: Filed: Routed:

Further Action Required (i.e., RML, Senior Management Attention, etc.) $\therefore$ 
From: TWRS FAR Engineering

Phone: $\quad 376-4567$ A3-37

Date: August 8, 1995

Subject: CONSEQUENCES OF BURNING 60 GALLONS OF DIESEL FUEL

To:
R. D. Crowe
HO-32
D. S. Leach
A3-34
A. K. Postma
G\&P Consultants
Cc: S. Mtahl
W. L. Cowley
A3-37
A3-37

You asked if burning 60 gallons of diesel fuel in an underground storage tank would be bounded by the consequences that are analyzed in the organic solvent fire accident. I discussed the question with Arlin Postma of G\&P consultants, and we decided that our accident analyses would be bounding for your diesel fire.

We specifically looked at the case of a large pool fire in an SST which gives the maximum radiological consequences and produces the largest pressure transient. This is case $g$ in our spreadsheet. The configuration is a pool 210 square meters in area on the top of the waste surface. The tank has an active ventilation system. The mass of solvent burned is 146 $\mathrm{kg}$ 's. The only vent path is through the HEPA filter on the ventilation system.

Our model assumes that the solvent is $84 \%$ NPH and $16 \%$ TBP. To model the properties of NPH, we used dodecane. Since the model assumes $84 \% \mathrm{NPH}$, the properties we used for the model are nearly identical to pure dodecane. We believe that the properties of dodecane are a good representation for diesel oil. Therefore we think it is reasonable to assume that our model, which is based on dodecane, is also a good model for diesel fuel.

The stoichiometry of burning dodecane and diesel should be nearly the same in terms of moles of oxygen consumed. Therefore we expect both the dodecane and diesel fires to self extinguish when the oxygen concentration in the air is approximately 13 mole percent.

Our model uses a $\mathrm{flame}$ spread velocity of $10 \mathrm{~cm} / \mathrm{sec}$. This value comes from tests of unconfined poois of jet fuel. The rate at which jet fuel (essentially kerosene) burns is a good approximation of the rate at which diesel oil burns.

Our case g self extinguishes after $146 \mathrm{~kg}$ 's of solvent are burned. Using 0.75 for the SpG of diesel oil and $8.34 \mathrm{lbs} / \mathrm{gal}$ for the density of water, the $146 \mathrm{kgs}$ of solvent would be equivalent to $51.3 \mathrm{gallons}$ of diesel fuel. The maximum amount of diesel ail that would burn before self extinguishment is 51.3 gallons. The consequences of burning the diesel oil are bounded by the consequences of burning $146 \mathrm{~kg}$ 's of solvent. Similar 
R. D. Crowe

Page 2

August 8, 1996

reasoning also demonstrates that your 60 gallons of diesel fuel is bounded for SSTs and DCRTs by our accident analyses.

W. L. Cowley

Senior Principle Engineer

TWRS SAR Engineering

WLC . 


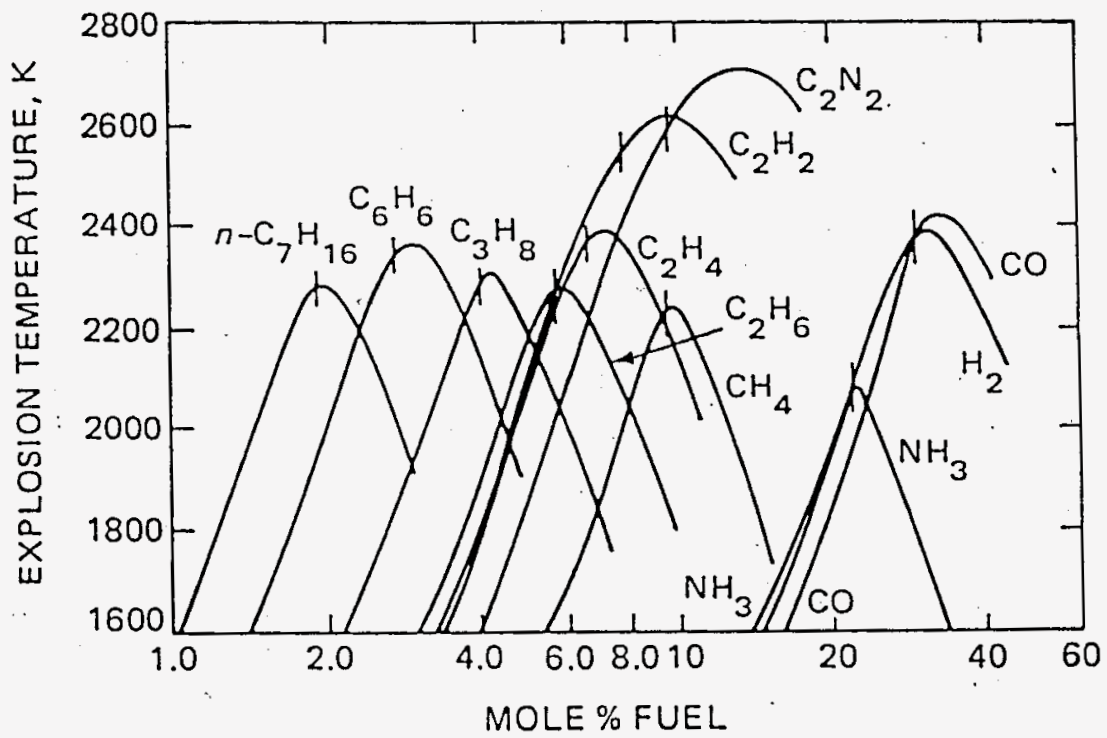

Fig. 2-5.4. The adiabatic constant-pressure explosion temperatures for a number of fuel-air mixtures. Initial conditions: $T=298.15 \mathrm{~K}, P=$ $101.325 \mathrm{kPa}$. The vertical bars represent stoichiometric mixtures. The . species $\mathrm{H}_{2}$ and $\mathrm{CO}$ share the same bar. ${ }^{13}$ 


\section{CHECKLIST FOR PEER REVIEW}

Document Reviewed: Calculation Notes that Support Accident Scenario and Consequence of the In-Tank Fuel Fire/Deflageration, WHC-SD-WM-CN-059, Rev 1.

Scope of Review: This review was limited to confirming that the comments to Rev 0 provided by this reviewer were dispositioned and/or incorporated into Rev 1 to my satisfaction.

Yes No NA

$[\mathrm{X}][\mathrm{]}] \mathrm{]}$
Previous reviews complete and cover analysis, up to scope of
this review, with no gaps.

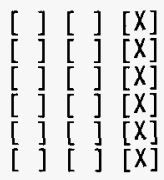
Problem completely defined.

Accident scenarios developed in a clear and logical manner. Necessary assumptions explicitly stated and supported. Computer codes and data files documented.

Data used in calculations explicitly stated in document.

Data checked for consistency with original source information as applicable.

[X] [ ] [ ] Mathematical derivations checked including dimensional consistency of results.

[ ] [ ] [X] Models appropriate and used within range of validity or use

[X] [ ] [ ]

[]$\left[\begin{array}{l}{[\mathrm{X}} \\ {[]}\end{array}\right][\mathrm{X}]$ outside range of established validity justified.

Hand calculations checked for errors. Spreadsheet results should be treated exactly the same as hand calculations. Software input correct and consistent with document reviewed. Software output consistent with input and with results reported in document reviewed.

[ ] [ ] $[\mathrm{X}]$

$\begin{array}{lll}{[\mathrm{C}} & {[\mathrm{X}} & {[\mathrm{X}]} \\ {[\mathrm{J}} & {[\mathrm{X}} & {[\mathrm{X}]} \\ {[\mathrm{H}} & {[\mathrm{X}]}\end{array}$ Limits/criteria/guidelines applied to analysis results are appropriate and referenced.

Limits/criteria/guidelines checked against references. Safety margins consistent with good engineering practices. Conclusions consistent with analytical results and applicable limits.

[ ] [ ] [X] Results and conclusions address all points required in the problem statement.

[ ] [ ] [X] Format consistent with appropriate NRC Regulatory Guide or other standards

[ ] $[\mathrm{X}]$ * Review calculations, comments, and/or notes are attached.

[X] [ ] [ ]

Tom Tomaszewski

Document approvod.

Reviewer (Printed Name and Signature)

$9 / 19 / 96$ Date

* Any calculations, comments, or notes generated as part of this review should be signed, dated and attached to this checklist. Such material should be labeled and recorded in such a manner as to be intelligible to a technically qualified third party. NONE ATTACHED.

[ ] [ ] [X] Analysis entered into analysis database

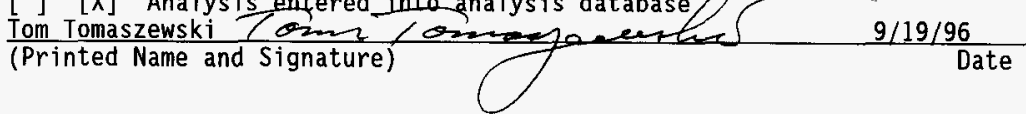




\section{DISTRIBUTION SHEET}

\begin{tabular}{|c|c|c|c|c|c|}
\hline \multirow{2}{*}{$\begin{array}{l}\text { To } \\
\text { Distribution }\end{array}$} & \multirow{2}{*}{\multicolumn{3}{|c|}{$\begin{array}{l}\text { From } \\
\text { R. D. Crowe }\end{array}$}} & \multicolumn{2}{|l|}{ Page 1 of 1} \\
\hline & & & & \multicolumn{2}{|c|}{ Date $09 / 19 / 96$} \\
\hline \multicolumn{4}{|l|}{ Project Title/Work Order } & \multicolumn{2}{|c|}{ EDT No. 618485} \\
\hline \multicolumn{4}{|c|}{$\begin{array}{l}\text { Calculation Notes That Support Accident Scenario and Consequence } \\
\text { Determination of the In-Tank Fuel Fire/Deflagration. }\end{array}$} & \multicolumn{2}{|c|}{ ECN No. 634488} \\
\hline Name & MSIN & $\begin{array}{c}\text { Text } \\
\text { With All } \\
\text { Attach. }\end{array}$ & Text Only & $\begin{array}{l}\text { Attach./ } \\
\text { Appendix } \\
\text { Only }\end{array}$ & $\begin{array}{l}\text { EDT/ECN } \\
\text { Only }\end{array}$ \\
\hline $\begin{array}{l}\text { E. R. Bruschi } \\
\text { C. Carro } \\
\text { R. D. Crowe ( } 3 \text { ) } \\
\text { S. H. Finfrock } \\
\text { D. S. Leach } \\
\text { A. E. Waltar } \\
\text { TWRS \& \& L Project Files (2) } \\
\text { Central Files (original +2) }\end{array}$ & $\begin{array}{l}A 2-34 \\
A 2-34 \\
H 0-32 \\
H 0-32 \\
A 3-34 \\
H 0-32 \\
A 2-26 \\
A 3-88\end{array}$ & $\begin{array}{l}x \\
x \\
x \\
x \\
x \\
x \\
x \\
x\end{array}$ & & & \\
\hline
\end{tabular}

